Original Article

\title{
ECOLOGY AND THE RAPD TECHNIQUES USED TO ASSESS THE GENETIC DIVERSITY IN PTEROLOBIUM HEXAPETALUM, A SCRAMBLING MEDICINAL SHRUB IN MARUTHAMALAI AND CHENNIMALAI HILLS, THE WESTERN GHATS
}

\author{
SHARMILA S. ${ }^{*}$, AKILANDESWARI D. ${ }^{2}$, RAMYA E. K. ${ }^{3}$, MOWNIKA S. ${ }^{4}$
}

1PG and Research Department of Botany, Vellalar College for Women (Autonomous), Thindal, Erode 638012, Tamil Nadu, India

Email: drsharmilas@yahoo.com

Received: 24 Nov 2018 Revised and Accepted: 26 Jan 2019

\section{ABSTRACT}

Objective: To investigate the ecological and genetic diversity, climatic factors, edaphic factors morphological and reproductive characters and RAPD analysis of medicinal plant species Pterolobium hexapetalum in two hills viz., Maruthamalai (arid) and Chennimalai (very arid), which is located in Coimbatore and Erode districts, Tamil Nadu.

Methods: The present research was carried out by using a random amplified polymorphic DNA (RAPD) analysis was made to determine the genetic variation between the two populations of the medicinal shrub, Pterolobium hexapetalum in an environmental gradient. Among the five primers tested, the OPN7 (80\%) and OPN17 (71.4 \%) produced higher polymorphism was used in RAPD analysis.

Results: The results of RAPD analysis showed the presence of 51 individual bands were formed, out of which, 29 were polymorphic bands which showed the existence of genetic variation between populations. A dendrogram was constructed based on Jaccard's coefficient to determine the degree of genetic relationship among the two populations and analysed. The primers OPN7 and OPN17 were clustered together at a genetic distance level 10. Considering the elevation and proximity, the temperature ranges from $18{ }^{\circ} \mathrm{C}$ to $37.6{ }^{\circ} \mathrm{C}$ in Maruthamalai hill and $20{ }^{\circ} \mathrm{C}$ to $39.4{ }^{\circ} \mathrm{C}$ in Chennimalai hill.

Conclusion: From the morphoecological studies the results indicated that both arid and very arid climatic conditions showed slight differences in their vegetative and reproductive characters.

Keywords: Genetic diversity, RAPD, Pterolobium hexapetalum, Jaccard's coefficient

(c) 2019 The Authors. Published by Innovare Academic Sciences Pvt Ltd. This is an open access article under the CC BY license (http://creativecommons.org/licenses/by/4.0/) DOI: http://dx.doi.org/10.22159/ijpps.2019v11i3.30983

\section{INTRODUCTION}

Biodiversity is the total variety of life on earth. It includes all genes, species and ecosystem. In short it reflects the totality of genes, species and ecosystems [1]. Herbal medicine is the foundation for about $75-80 \%$ of world population, mainly targeting primary health care in upward countries because of better cultural acceptability, compatibility with human body, low cost and lesser side effects. India is endowed with a rich wealth of medicinal plants. India recognizes more than 2500 plant species which medicinal values. Plants are like natural laboratories where great numbers of chemicals are biosynthesized and fact they may considered the most important source of chemical compounds [2].

Plants respond biologically to various parameters in the holocoenotic environment. Besides this, many extrinsic factors like time of phenophase and seed dispersal are very significant factors indistribution, survival and success in the establishment of a species in the community [3]. Considering these facts, a present ecological and genetic diversity studies were conducted for Pterolobium hexapetalum (Roth.) Santapau and Wagh species in Maruthamalai and Chennimalai hills. It is known that ecological studies are important for the conservation of genetic resources and forest management as well as for a better understanding of ecological capabilities of plant species and community-level interactions.

The study area Maruthamalai hill, located in Coimbatore district harbor a rich source of plant species belongs to different life forms and many of the species are recognized as medicinally important. Another study area is Chennimalai hill, situated in Erode district embraces rare medicinal herbs in its lush green forests. The hill is noted for its natural flora and fauna. In the observation point of view, the commonly available Pterolobium hexapetalum is found to be a medicinally important species in this region. Consequently, this plant species has been selected for diversity and pharmacognostical studies.
Pterolobium hexapetalum (Roth.) Santapau and Wagh is one of the large scrambling shrub belonging to Leguminosae family having significant medicinal properties. The leaves and stem bark of this plant are widely used as curing agent to cure cough for children and delivery pains. In India the study species is abundant in the foothills of the Western Ghats at different environmental conditions with distinct morphological variation. Hence, to determine the genetic variation between the same species in two hills, Random Amplified Polymorphic DNA (RAPD) analysis was carried out by using RAPD markers. This technical analysis has been extensively used for various purposes which include identification and classification of accessions [4], identification of breeds [5] and genetic diversity analysis [6].

\section{MATERIALS AND METHODS}

Ecological and genetic diversity studies

Study area

In the present study an attempt has been made to enumerate the ecological and genetic diversity of single medicinal plant species Pterolobium hexapetalum (voucher specimen number-BSI/SRC/ 5/23/2016/Tech./2824). In two different hills viz., Maruthamalai and Chennimalai. This is located in Coimbatore district and Erode district, Tamil Nadu, India.

\section{Climatology}

Climatic data such as temperature, rainfall, rainy days and relative humidity of Maruthamalai hill were collected from District Forest Office, Coimbatore Circle, Tamil Nadu, India. Same data's related to Chennimalai hill were collected from the Deputy Director General of Meterology, Regional Metrological Centre, Meterological Department, Chennai, Tamil Nadu, India. 


\section{Soil sample collection and analysis}

Soil samples were randomly collected three times from the two study areas. Samples were collected only from surface level and brought to the laboratory in sterile polythene bags for further analysis.

\section{Soil texture}

The texture of soil samples in two areas were calculated by Pipette method [7].

\section{Hydrogen ion concentration $(\mathrm{pH})$}

The $\mathrm{pH}$ of soil samples were measured in $\mathrm{pH}$ meter. The soil samples were diluted at 1: 2.5-soil: water ratio. The $\mathrm{pH}$ of the solution was measured using a $\mathrm{pH}$ meter, calibrated with standard buffer solution prior to use.

\section{Electrical conductivity (EC)}

Electrical conductivity (EC) was measured in soil samples and prepared for analyzing total amount of soluble salts present in the soil. The electrical conductivity (EC) is expressed as dsm-1. The EC of the soil extract was determined by using systronic EC meter (digital) in a soil water suspension of 1: 5 ratios [7].

Determination of available nitrogen, phosphorus, potassium and micronutrients viz., $\mathrm{Fe}, \mathrm{Mn}, \mathrm{Zn}$ and $\mathrm{Cu}$ in soil were analysed $[8,11]$.

\section{Morphological characters of the study plant in study area}

\section{Shoot, root, pod lengths and stem girth}

The shoot, root, pod lengths and stem girth of Pterolobium hexapetalum triplicate values were randomly measured and the mean values were expressed in $\mathrm{cm}$.

\section{Lateral roots, branches and leaves per plant}

The lateral roots, branches and leaves per plant of Pterolobium hexapetalum has been identified, calculated and the mean values were expressed in numbers.

\section{Leaf thickness}

The leaf thickness of Pterolobium hexapetalum was measured and the mean values were expressed in $\mathrm{mm}$.

\section{Leaf surface area}

The leaf surface area of study species has been measured and the mean values were expressed in $\mathrm{cm}^{2}$.

\section{Inflorescence per branch}

The inflorescence per branch of Pterolobium hexapetalum has been identified, calculated and the mean values were expressed in numbers.

\section{RAPD analysis}

In order to evaluate the genetic diversity in Pterolobium hexapetalum population in two hills the RAPD technique was used. The young tender leaves of Pterolobium hexapetalum individuals were collected from two study areas and were washed with double distilled water then stored in sealed polythene bags at- $70{ }^{\circ} \mathrm{C}$ in a deep freezer until analysis. Genomic DNA was isolated from $100 \mathrm{mg}$ of the leaf tissue by using GenElute plant genomic DNA purification kit (Sigma-Aldrich) and following the manufacturer's instructions. Genomic DNA was extracted by the CTAB method [12] with some modifications.

\section{Quality check and quantification of genomic DNA}

About $2 \mu$ of the genomic DNA was isolated from $100 \mathrm{mg}$ of leaf tissue. This was subjected to electrophoresis on a $0.8 \%$ agarose gel containing $0.5 \mu \mathrm{g} / \mathrm{ml}$ of ethidium bromide. After electrophoresis, the gel was viewed over a UV transilluminator (UVT-40M, Herolab) and the quality and quantity of the DNA were assessed by using undigested $\lambda$ DNA as a control. The genomic DNA was diluted to $4 \mathrm{ng} / \mu \mathrm{l}$ and stored at $4{ }^{\circ} \mathrm{C}$ as a working solution while the stock DNA (undiluted) was stored at$20^{\circ} \mathrm{C}$ in aliquots.

\section{PCR mixture}

The primers used for PCR amplification were purchased from Bio Basic Inc. PCR amplification reactions were carried out in a $20 \mu \mathrm{l}$ reaction volume. The PCR reaction was perform using $2 x$ DyNAzyme II PCR Master Mix (10 $\mu$ l), Primer $(10 \mu \mathrm{M})-1 \mu \mathrm{l}, \mathrm{DW}(7 \mu \mathrm{l})$ and DNA (2 $\mu \mathrm{l})$. The amplification program consist in an initial denaturation step at $95^{\circ} \mathrm{C}$ for $5 \mathrm{~min}$, followed by 40 cycles of denaturation at $94{ }^{\circ} \mathrm{C}$ for $0.30 \mathrm{~min}$, annealing at $35^{\circ} \mathrm{C}$ for $1 \mathrm{~min}$ and elongation for $2 \mathrm{~min}$ at 72 ${ }^{\circ} \mathrm{C}$ and a final extension step at $72{ }^{\circ} \mathrm{C}$ for $10 \mathrm{~min}$. A negative control without genomic DNA template was used for amplification along with genomic DNA from two habitats with primers. This was done to confirm the quality of primer dimers or possible contaminants. The gels were visualized under UV transilluminator (Genei) and the image was captured under UV light using Gel documentation system (Bio-Rad).

Table 1: Details of sequence and melting temperature of the RAPD primers

\begin{tabular}{lll}
\hline RAPD primer & Primer sequence & Tm \\
\hline OPN2 & ACCAGGGGCA & 34.94 \\
OPN4 & GACCGACCCA & 29.8 \\
OPN7 & CAGCCCAGAG & 25.29 \\
OPN15 & CAGCGACTGT & 19.87 \\
OPN17 & CATTGGGGAG & 25.36 \\
\hline
\end{tabular}

\section{Data analysis}

DNA fragment size was estimated by comparing the DNA bands against the DNA ladder (Bangalore Genie, India). The amplified DNA bands were scored on gel as 1 for the presence and 0 for the absence of bands and assembled in the data matrix table 1 . The pair wise comparisons were calculated using Nei and Li's coefficient [13]. The similarity values found were utilized to group individuals via the unweighted pair group method with arithmetic average (UPGMA). NTSYS-PC was used to perform all the analysis [14].

\section{RESULTS}

The herbal medicines on the plant resources are comparatively safer than synthetic drugs. Nowadays the medicinal plants used in alternate medicine are awaiting a touch of modern knowledge. The ecological studies are important for the conservation of genetic resources and forest management as well as for a better understanding of ecological capabilities of plant species and community-level interactions [15]. The famous Maruthamalai hill consists of two types of vegetation namely southern tropical thorn forests and southern tropical dry deciduous forests [16]. Commonly available species are under trees, shrubs and medicinal plants with wealth forest products.

In the observation point of view, the commonly available Pterolobium hexapetalum is found to be a medicinally important species in two regions. Consequently, this plant species has been selected for diversity and pharmacognostical studies. In India it is recorded in the tropical and scrub jungles and dry deciduous forests. This species is globally distributed in the tropical regions [17]. The study area Maruthamalai hill consists of moist dry deciduous type of forest at an altitude of $426.72 \mathrm{msl}, 11.04$ ' E of longitude and 76.93' $\mathrm{N}$ of latitude. Another study area Chennimalai hill consists of a thornyscrub jungle forest embraces a rare medicinal herbs in its lush green forests (fig. 1). It is located at $77.62^{\prime} \mathrm{E}$ of longitude, $11.17^{\prime} \mathrm{N}$ of 
latitude and average elevation of $320 \mathrm{msl}$. The climatic data such as temperature, rainfall, rainy days and relative humidity of two study hills were presented for 12 mo from January 2016 to December 2016 (fig. 1-1a, 1b). The monthly average minimum temperature of study areas were ranged between $18{ }^{\circ} \mathrm{C}-26.1{ }^{\circ} \mathrm{C}$ and $20{ }^{\circ} \mathrm{C}-26.6{ }^{\circ} \mathrm{C}$. The monthly average maximum temperature ranged between 28.5 ${ }^{\circ} \mathrm{C}-37.6{ }^{\circ} \mathrm{C}$ and $29.6{ }^{\circ} \mathrm{C}-39.4{ }^{\circ} \mathrm{C}$. Another study area Chennimalai hill

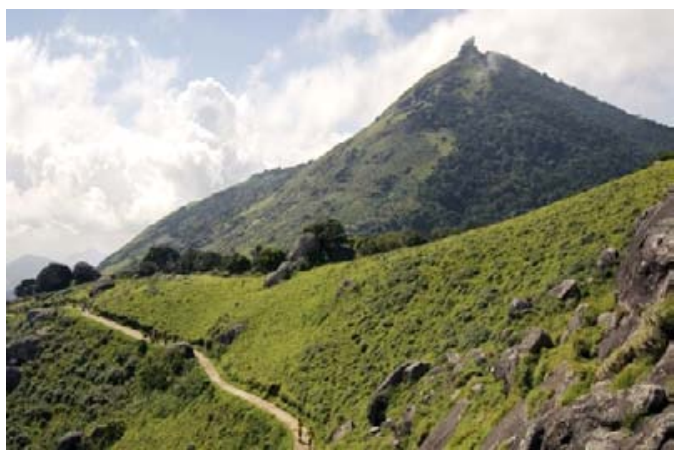

Hill view of Maruthamalai-study area is characterized by warm climate with low humidity owing to altitude and vegetation. The forest consists of two zones, the scrub jungle at foot hill and dry deciduous forest in middle and upper zones. An indiscriminate quarrying of stones from a hillock, destroyed a quite number of valuable medicinal plants and also affected the local geography in the form of depletion of water resources and fauna [18].

Fig. 1a: Climatic factors of the study area-maruthamalai hill
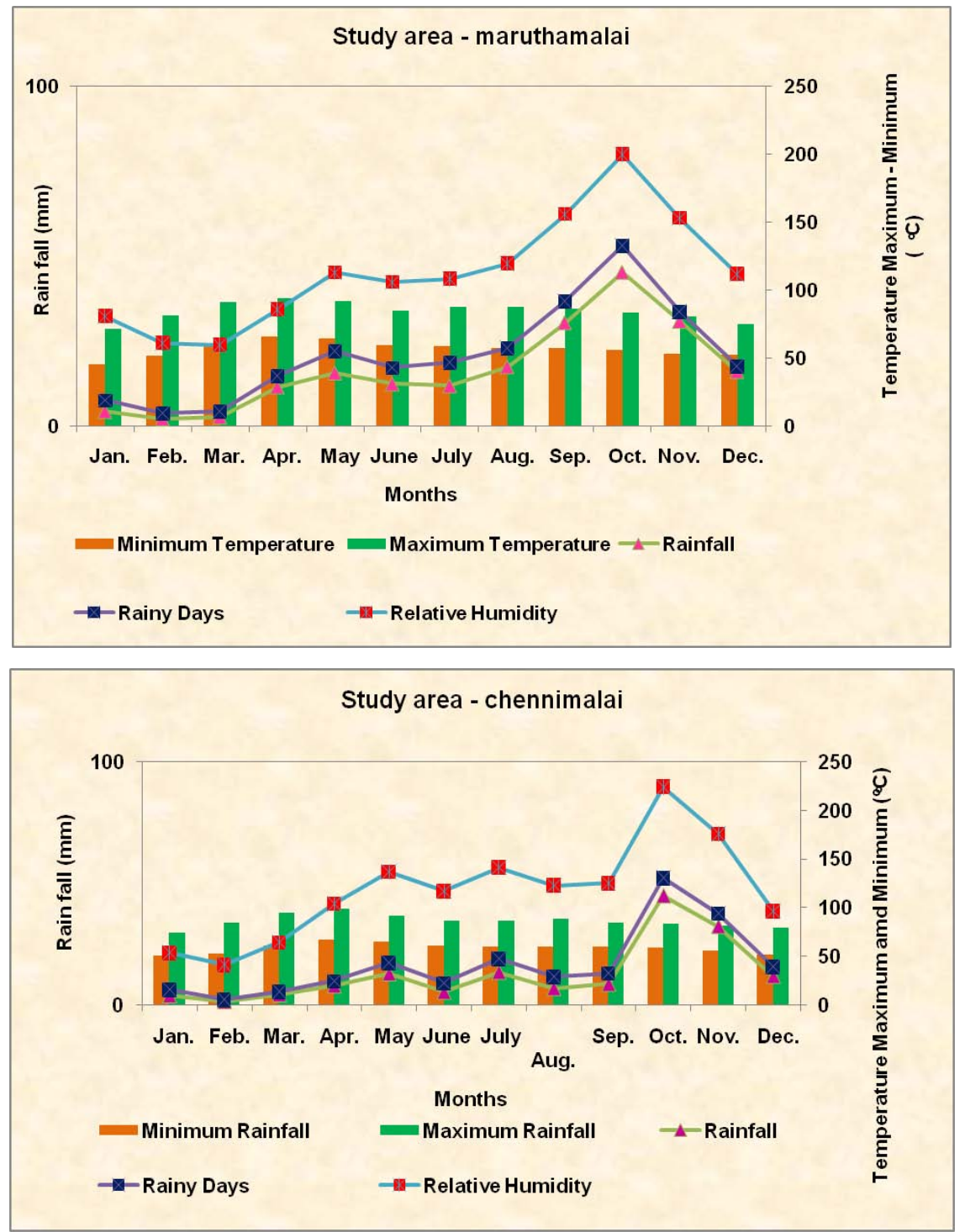

Fig. 1b: Climatic factors of the study area-chennimalai hill 
The monthly rainfall values ranged from $5.08 \mathrm{~mm}$ to $112.79 \mathrm{~mm}$ in Maruthamalai region and $2.90 \mathrm{~mm}$ to $112.5 \mathrm{~mm}$ in Chennimalai region. The total rainfall for the year 2016 (January to December) was $498.79 \mathrm{~mm}$ and $379.88 \mathrm{~mm}$ respectively. The relative humidity of Maruthamalai was ranged between $49 \%-69 \%$ and in Chennimalai it was recorded in the range of $36 \%$ and $95 \%$. These results are in agreement with Sarvalingam et al. [16] who reported the climatic factors of Maruthamalai hill previously. Anjanadevi [19] opined that the variability in altitude, latitude, climate, rainfall and soil has contributed to the rich floristic diversity of the hill which can rightly be called as treasure house of medicinal plants.

The physico-chemical characters and distribution of minor and major elements in soil samples around the root system are shown in table 2. In the study areas, the analysis of micronutrients such as $\mathrm{Fe}, \mathrm{Mn}, \mathrm{Zn}$ and $\mathrm{Cu}$ in soil samples revealed that ferrous content was dominant in both the hills (Maruthamalai-6.71 $\pm 0.71 \mathrm{ppm}$; Chennimalai-5.24 $\pm 0.02 \mathrm{ppm}$ ) followed by zinc $(2.56 \pm 0.06 \mathrm{ppm} ; 1.91 \pm 0.03 \mathrm{ppm})$, manganese $(1.51 \pm 0.01 \mathrm{ppm} ; 1.27 \pm 0.01 \mathrm{ppm})$ and copper $(0.91 \pm 0.02 \mathrm{ppm}$; $0.89 \pm 0.03 \mathrm{ppm})$. Among the ecological studies of two hills, Maruthamalai hill represented higher values in all tested parameters. In earlier days several authors said that the soil nutrients are essential for plant growth. Zinc is an essential micro-nutrient for plant growth and development. The zinc occurs as a free ion that drives and boosts the rate of many metabolic reactions of the plants $[20,21]$.

Table 2: Physico-chemical characteristics of rhizospheric samples of study area

\begin{tabular}{lll}
\hline Parameter & Study area & \\
\cline { 2 - 3 } & Maruthamalai & Chennimalai \\
\hline Soil texture & Sandy loamy & Slit mixed with coarse sand \\
pH & $7.00 \pm 1.73$ & $6.90 \pm 0.76$ \\
EC $\left(\mathrm{dsm}^{-1}\right)$ & $0.80 \pm 0.10$ & $0.56 \pm 0.13$ \\
$\mathrm{~N}(\%)$ & $62.00 \pm 4.58$ & $59.66 \pm 5.50$ \\
$\mathrm{P}(\%)$ & $39.16 \pm 3.32$ & $24.68 \pm 1.34$ \\
$\mathrm{~K}(\%)$ & $844.33 \pm 7.23$ & $722.96 \pm 1.53$ \\
Fe (ppm) & $6.71 \pm 0.71$ & $5.24 \pm 0.02$ \\
Mn (ppm) & $1.51 \pm 0.01$ & $1.27 \pm 0.01$ \\
Zn $(\mathrm{ppm})$ & $2.56 \pm 0.06$ & $1.91 \pm 0.03$ \\
$\mathrm{Cu}(\mathrm{ppm})$ & $0.91 \pm 0.02$ & $0.89 \pm 0.03$ \\
\hline
\end{tabular}

\#Values are means of triplicate determinations \pm Standard Deviation

The morphological and reproductive characters of Pterolobium hexapetalum in two natural resources are shown in table 3 . The highest shoot length was observed in Maruthamalai hill in the range of $161.66 \pm 10.69 \mathrm{~cm}$ whereas; in Chennimalai it was in the range of $157.33 \pm 11.06 \mathrm{~cm}$. The suppression of vegetative growth in very arid place (Chennimalai) concomitantly enhanced some phenological characters such as root length, lateral roots, leaflets thickness and reproductive ability of the species $(57.33 \pm 10.06 \mathrm{~cm}$; $19.66 \pm 5.68 ; 0.27 \pm 0.10 \mathrm{~mm} ; 15.33 \pm 1.52$ ). The other vegetative traits of this plant, viz., stem girth, number of branches per plant, number of leaflets per branch and leaflet surface area were higher in arid region of Maruthamalai $(1.56 \pm 0.30 \mathrm{~cm} ; 46.33 \pm 8.73$;
$1761.33 \pm 194.01 ; 2.06 \pm 0.51 \mathrm{~cm}^{2}$ ). Reproductive attribute like pod length was lower in Chennimalai region $(3.33 \pm 0.75 \mathrm{~cm})$, the same was higher in Maruthamalai region $(5.10 \pm 1.37 \mathrm{~cm})$. The results indicated that both arid and very arid climatic conditions showed slight differences in their vegetative and reproductive characters. Phenotypic variation in plants, as in all organisms, results from a complex interplay of genetic and environmental factors [22]. Similar features were observed in Grevillea barklyana [23,24] for many wild plants. Among the ecological studies of two hills, Maruthamalai hill represented higher values in all tested parameters. In earlier days several authors said that the soil nutrients are essential for plant growth.

Table 3: Morphological and reproductive characters of Pterolobium hexapetalum

\begin{tabular}{|c|c|c|c|}
\hline \multirow[t]{2}{*}{ S. No. } & \multirow[t]{2}{*}{ Characters } & \multicolumn{2}{|l|}{ Study area } \\
\hline & & Maruthamalai & Chennimalai \\
\hline 1. & Climatic condition & Arid & Very arid \\
\hline 2. & Shoot length $(\mathrm{cm})$ & $161.66 \pm 10.69$ & $157.33 \pm 11.06$ \\
\hline 3. & Root length $(\mathrm{cm})$ & $55.66 \pm 9.07$ & $57.33 \pm 10.06$ \\
\hline 4. & No. of lateral roots/plant (numbers) & $16.33 \pm 2.51$ & $19.66 \pm 5.68$ \\
\hline 5. & Stem girth $(\mathrm{cm}) /$ plant & $1.56 \pm 0.30$ & $1.30 \pm 0.10$ \\
\hline 6. & No. of branches/plant (numbers) & $46.33 \pm 8.73$ & $33.66 \pm 9.29$ \\
\hline 7. & No. of leaflets/branch (numbers) & $1761.33 \pm 194.01$ & $1382.66 \pm 167.67$ \\
\hline 8. & Leaflet thickness (mm) & $0.23 \pm 0.86$ & $0.27 \pm 0.10$ \\
\hline 9. & Leaflet surface area $(\mathrm{cm} 2)$ & $2.06 \pm 0.51$ & $1.98 \pm 0.37$ \\
\hline 10. & No. of inflorescence/branch (numbers) & $11.66 \pm 1.15$ & $15.33 \pm 1.52$ \\
\hline 11. & Pod length $(\mathrm{cm})$ & $5.10 \pm 1.37$ & $3.33 \pm 0.75$ \\
\hline
\end{tabular}

\#Values are means of three independent analysis \pm Standard Deviation

Random amplified polymorphic DNA (RAPD) markers have been used to characterize the genetic diversity in a number of medicinal and aromatic plants $[25,26]$. Genetic diversity statistical analysis of polymorphic primers for Pterolobium hexapetalam was predicted in table 4 . A total of 51 individual bands were formed, out of which, 29 were polymorphic bands (fig. 2). Among the five primers tested, the OPN7 (80\%) and OPN17 (71.4\%) produced higher polymorphism followed by the OPN4 (50\%), OPN2 and OPN15 (46.7\%) with lower polymorphism. The amount of polymorphism per fragment was used to calculate the percentage of polymorphism. Similar observations were noted and recorded $[27,28]$ 
Table 4: RAPD-statistical analysis of polymorphic primers for $P$. hexapetalum sample

\begin{tabular}{llll}
\hline RAPD primer & Total no. of bands & Polymorphic bands & Polymorphism (\%) \\
\hline OPN2 & 15 & 7 & 46.7 \\
OPN4 & 4 & 2 & 50.0 \\
OPN7 & 7 & 5 & 71.4 \\
OPN15 & 15 & 7 & 46.7 \\
OPN17 & 10 & 8 & 80.0 \\
\hline
\end{tabular}

The dendrogram analysis revealed two major clusters (fig. 3). The primers OPN2, OPN4 and OPN15 were together formed the first cluster. The other primers OPN7 and OPN17 formed the second cluster. The two clusters were connected at a genetic distance level 30. The primers OPN2 and OPN15 were clustered at 0.000 genetic distances and the primer OPN4 clustered at about 12.5 genetic distances. The primers OPN7 and OPN17 were clustered together at a genetic distance level 10 . The similarity indexes of Pterolobium hexapetalam for 5 different primers were revealed that the sample of same species from two different origins shows similarities. The sample indicates that low variability between individuals of different origin. The higher similarity indices advocate that the individuals have closer genetic relation. The observations of slight changes between the same species in two hills are mainly due to ecological conditions of the soil. This may changes the quantity of active compounds present in them. This is in agreement with the results of Sathishkumar et al., [27] who studied the genetic variation between the five populations of the medicinal shrub, Acacia caesia var. caesia in an environment gradient by RAPD analysis.

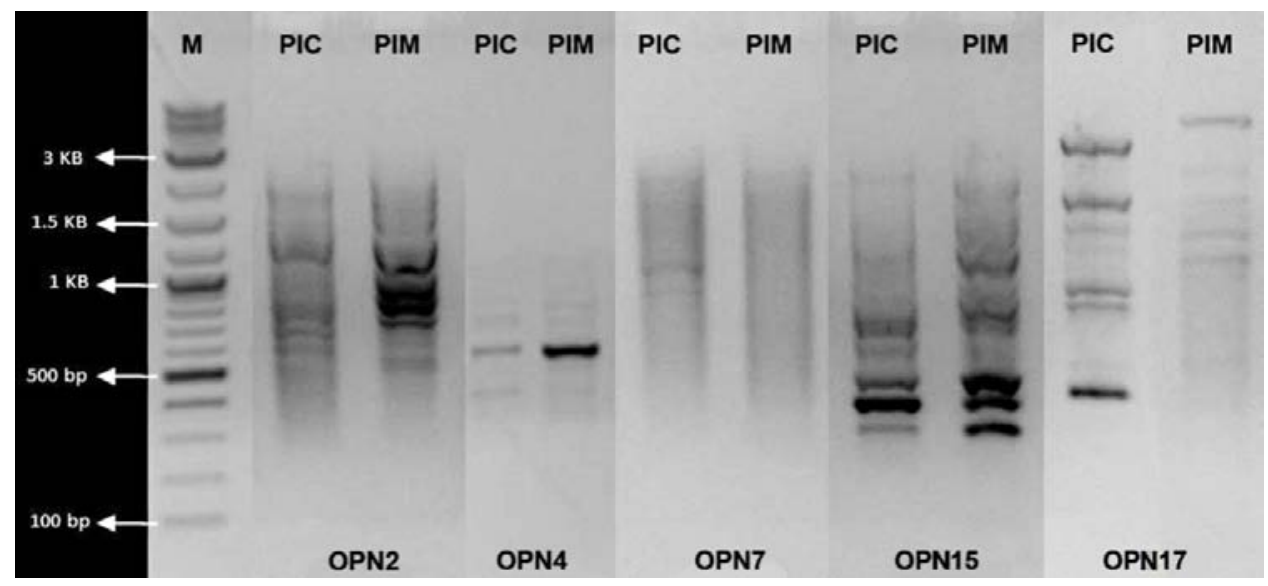

Fig. 2: RAPD fragments banding pattern of Pterolobium hexapetalum individuals, Lane M-marker 100 bp ladder, 'PIC' indicate Pterolobium indicum species in Chennimalai, PIM' indicate Pterolobium indicum in Maruthamalai

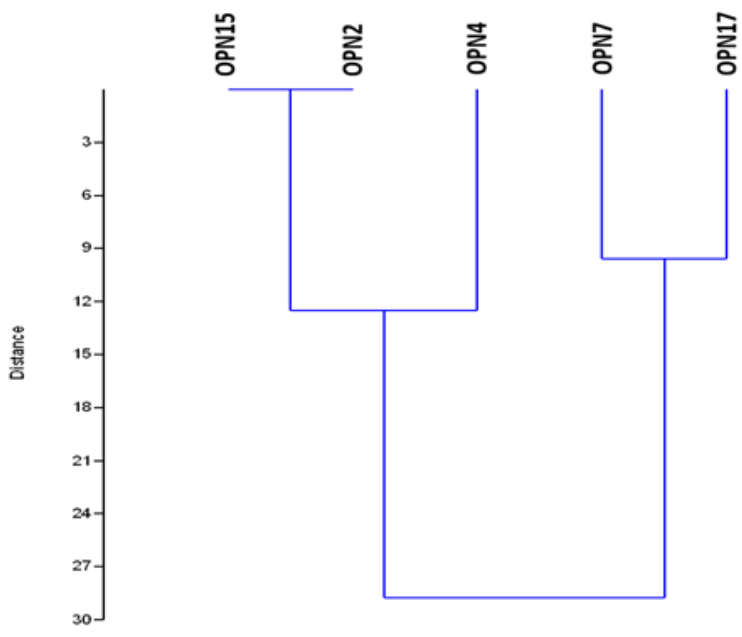

Fig. 3: Dendrogram analysis using Jaccard's similarity coefficient and UPGMA clustering for Pterolobium hexapetalum sample

\section{CONCLUSION}

A close look at the medicinal plants of western tropical mixed dry deciduous and shrub jungle forests in Maruthamalai and Chennimalai hills revealed that they possess several curative properties due to some active principles. The findings of the present investigation in two study hills showed that the general macroclimate and local microclimate are favourable for rich diversity of plant species with respect to medicinal flora. The similarity indexes of Pterolobium hexapetalam for 5 different primers were revealed that the sample of same species from two different origins shows similarities. The sample indicates that low variability between individuals of different origin. The higher similarity indices advocate that the individuals have closer genetic relation. The observations of slight changes between the same species in two hills are mainly due to ecological conditions of the soil. This may changes the quantity of active compounds present in them. All characters obtained from the results are also required for database preparation in this digital world by which further experiments or research can be preceded.

\section{ACKNOWLEDGEMENT}

This research did not receive any specific grant from funding agencies in the public, commercial, or not-for-profit sectors.

\section{AUTHORS CONTRIBUTIONS}

All the author have contributed equally

\section{CONFLICT OF INTERESTS}

Declared none

\section{REFERENCES}

1. FES. Assessment of biodiversity in sitamata wildlife sanctuary a conservation perspective. Report of Foundation for Ecological Security, Gujarat, India; 2010. 
2. Kirtikar KR, Basu BD. Indian medicinal plants. 2nd edn. Vol 2. Bishen Singh Mahendra Pal Singh, Dehradun, India, International book distributor; 1975. p. 894-5.

3. Suresh D, Paulsamy S. Phenological observation and population dynamics of six uncommon medicinal plants in the grasslands of Nilgiris, Western Ghats, India. Maejo Int J Sci Technol 2010;4:185-92.

4. Fukuoka M, Niitani H, Suzuki A, Motomiya M, Hasegawa K, Nishiwaki Y, Kuriyama T, et al. A phase II study of CPT-11, a new derivative of camptothecin, for previously untreated nonsmall-cell lung cancer. J Clin Oncol 1992;10:16-20.

5. Qian Q, Hong C, Zongxiu S, Lihuang Z. The study on determining true and false hybrid rice; 1996.

6. Cao D, Oard JH. Pedigree and RAPD based DNA analysis of commercial U. S rice cultivars. Crop Sci 1997;37:1630-5.

7. Piper CS. Soil and plant analysis. Hans Publisher, Bombay; 1966.

8. Subbaiah BV, Asija GL. A rapid procedure for the estimation of available nitrogen in soil. Curr Sci 1956;25:259.

9. Olsen S, Cole C, Watanabe F, Dean L. Estimation of available phosphorus in soils by extraction with sodium bicarbonate. USDA Circular Nr 939, US Gov. Print. Office, Washington, D. C; 1954.

10. Jackson ML. Soil chemical analysis. Prentice Hall of India Pvt. Ltd, New Delhi; 1973. p. 38-56.

11. Lindsay WL, Norvell WA. Development of a DTPA soil test for zinc, iron, manganese and copper. Soil Sci Soc A J 1978;42:421-8.

12. Carlson JE, Tulsieram LK, Glaubitz JC, Luk VWK, Kauffeldt C, Rutledge R. Segregation of random amplified DNA markers in FI progeny of conifers. Theor Appl Genet 1991;83:194-200.

13. Nei N, Li W. Mathematical model for studying genetic variation in terms of restriction endonucleases. Proc Natl Acad Sci USA 1979;76:5269-73.

14. Rolf FJ. NTSYS-PC numerical taxonomy and multivariate system, Version 1.80; 1993.

15. Kunwar RM, Bussmann RW. Ethanobotany in the Nepal Himalaya. J Ethnobiol Ethnomed 2008;4:11.

16. Sarvalingam A, Rajendran A, Sivalingam R. Wild edible plant resources used by irulas of the maruthamalai hills. Southern Western Ghats, Coimbatore, Tamilnadu. Indian J Nat Prod Resour 2014;5:198-201.
17. Ganesh P, Nagendrababu G, Sudarsanam G. Pharmacognostical and analytical studies of leaves of pterolobium hexapetalum (Roth) santapau and wagh. J Pharm Res 2014;8:541-7.

18. Sindhu S, Uma G, Kumudha P. Survey of medicinal plants in Chennimallai Hills, Erode Districts, Tamilnadu. Asian J Plant Sci Res 2012;2:712-7.

19. Anjanadevi N. Survey of sporadic medicinal plants in Kanjamalai, Salem District IOSR J Human Soc (IOSR-JHSS); 2015. p. 92-4.

20. Parisi AF, BL Vallee. Zinc metalloenzymes: characteristics and significance in biology and medicine. Am J Clin Nutr 1969;22:1222-39.

21. Beulah Jerlin, Sharmila S, Kathiresan K, Kayalvizhi K. Zinc solubilizing bacteria from rhizospheric soil of mangroves. Int J Microbiol Biotechnol 2017;2:148-55

22. Lewontin RC. The genetic basis of evolutionary change. Columbia University Press: New York, USA; 1974.

23. Patrica M Hogbin, Ayre DJ, Whelan RJ. Genetic variation and reproductive success of road verge populations of the rare shrub Grevillea barklyana (Proteaceae). J Hered 1998;80:1806.

24. Chandler JW, Bartels D. Drought: avoidance and adaptation. In: Encyclopedia of Water Science. 2nd Edition. SW Trimble, BA Stewart, TA Howell. Taylor and Francis Group, London; 2008. p. 224.

25. Singh A, Dwivedi S, Bharti S, Srivastava A, Singh V, Khanuja S. Phylogenetic relationships as in Ocimum revealed by RAPD markers. Euphytica 2004;136:11-20.

26. De Masi L, Siviero P, Esposito C, Castaldo D, Siano F, Laratta B. Assessment of agronomic, chemical and genetic variability in common Basil (Ocimum basilicum L.). Eur Food Res Technol 2006;223:273-8.

27. Sathishkumar P, Paulsamy S, Anandakumar AM. Variation in physical characters and evaluation of genetic diversity in Acacia caesia var. caesia (L.) Willd. in an environmental gradient in the Western Ghats of Tamil Nadu, India. Maejo Int J Sci Technol 2010;4:533-9.

28. Gurudeepan S, Ramanathan T, Satyavani K, Dhinesh T. Standardisation of DNA isolation and PCR protocol for RAPD analysis of Suaeda sp. Asian J Biotechnol 2011;3:486-92. 